\title{
STIMULATION OF THE PITUITARY-ADRENAL AXIS WITH ARGININE VASOPRESSIN IN PATIENTS WITH DEPRESSION
}

\author{
William H. Meller*, Roger C. Kathol $\dagger$, Richard S. Jaeckle* and Juan F. Lopez $\ddagger$ \\ *Department of Psychiatry and †Departments of Psychiatry and Internal Medicine The University of Iowa \\ Hospitals, Iowa City, IA 52242; $¥$ Mental Health Research Institute University of Michigan Medical Center Ann \\ Arbor, MI 48109-0010, U.S.A.
}

(Revised 5 December 1986)

\begin{abstract}
Summary-The ACTH response to arginine vasopressin was the same in patients with depression while cortisol response was significantly greater in patients with depression when compared to the control population. These findings are consistent with the hypothesis that vasopressin corticotroph receptors are not downregulated in depression and that there is increased adrenal responsiveness in patients with depression to endogenous ACTH.
\end{abstract}

\section{INTRODUCTION}

ABNormalities of the hypothalmic-pituitary-adrenal (HPA) axis in patients with major depressive disorder have been well described (SACHAR et al., 1973; CARRoli et al., 1981; SCHLESSER et al., 1981). Much research has focused on suppression of the HPA axis with dexamethasone; however, few investigators have studied ACTH and cortisol response to vasopressin in affective illness.

Vasopressin is a nonapeptide which is known to stimulate the pituitary-adrenal axis in rats (MCCANN and BROBEK, 1959) and in humans (MCDonALD and WeISE, 1956). It acts through release of ACTH rather than having a direct effect on the adrenal gland (GWINUP, 1965; GwINUP et al., 1967) and was one of the principal agents used to stimulate ACTH secretion prior to the discovery of corticotropin releasing hormone (CRH) (LANDON et al., 1965). Although a portion of vasopressin is co-localized and possibly co-released with $\mathrm{CRH}$ in certain cells of the parvocellular region of the paraventricular nucleus of the hypothalamus, evidence from immunohistochemical methods (SAWCHENKE et al., 1984) as well as differential models of stress (GIBBs, 1986) suggest that regulation of vasopressin release can be independent of the release of CRF. Recently, investigators have identified receptors which are specific for arginine vasopressin on cells from the anterior pituitary (LUTZ-BUCHER and KoCH, 1983; KоCH and LUTZ-BUCHER, 1985). Binding of vasopressin to these receptors has been demonstrated to stimulate ACTH secretion (SPINEDI and NEGRoVILAR, 1984).

Three previous groups have used vasopressin to assess HPA axis function by measuring cortisol in patients with depressive disorders (JAKOBSON et al., 1969; CARROLL, 1972; KRAHN et al., 1985). The results of these investigations suggest that patients with depression have an abnormal cortisol response to vasopressin administration; however, the results are difficult to interpret. Two of these studies were uncontrolled and utilized lysine vasopressin, 
which causes significant adversive side effects, rather than AVP (JAKOBSON et al., 1969; CARroll, 1972). The third was controlled but suffered from small numbers and submaximal dosing of arginine vasopressin (AVP) (KRAHN et al., 1985).

Evidence supporting the hypothesis that HPA axis dysfunction in MDD may be the result of increased hypothalamic secretion of $\mathrm{CRH}$ is accumulating. In animal studies it has been shown that chronic administration of exogenous $\mathrm{CRH}$ causes increased secretion of ACTH, hypercortisolemia, and adrenal hypertrophy (RIVIER and VALE, 1983). There is also evidence to suggest that chronic stimulation with CRH may cause downregulation of the CRH receptor (RIVIER and VALE, 1983). In human studies NEMEROFF et al. (1984) have found elevated concentrations of $\mathrm{CRH}$ in the cerebrospinal fluid of patients with MDD. HoLSBOER et al. (1984) and GoLD et al. (1984) have found blunted ACTH response to exogenous CRH stimulation in patients with MDD and have suggested that ACTH hyporesponse is caused by elevated levels of circulating corticosteroids in depressed patients (HOLSBOER et al., 1984a; GolD et al., 1984). In two other studies, however, Holsboer failed to demonstrate a negative correlation between ACTH response to CRH and baseline cortisol levels in depressed patients (HolsBoER et al., 1984b, 1985). As an alternative mechanism he proposes that pituitary corticotroph cells may be desensitized by "persistent excessive hypothalamic release of corticotropin-releasing factor." This alternative view is supported by Lopez who found no correlation between baseline cortisol levels and ACTH response to insulin hypoglycemia (LOPEZ et al., 1987).

There is strong data, then, to support chronic hypersecretion of $\mathrm{CRH}$ and subsequent downregulation of pituitary $\mathrm{CRH}$ receptors as a biologic abnormality in MDD. In this study we hypothesize that a substance such as AVP which stimulates specific receptors unattenuated by $\mathrm{CRH}$ levels would cause normal release of ACTH and subsequent increased cortisol release from chronically stimulated and hyperresponsive adrenals.

\section{METHODS}

\section{Subjects}

Twenty-seven patients, 18 females and 9 males were recruited from the inpatient service of the University of Iowa Psychiatric Department. The mean age was $31.9 \pm 10.0$ (SD) with an age range of 21-58 yr. All met DSM-III criteria for a major depressive episode or bipolar affective disorder depressed type (AMERICAN Psychiatric Association, 1980). Diagnoses were confirmed by the NIMH Diagnostic Interview Schedule (DIS) (RoBINS, 1981). Mean Hamilton score was $18.9 \pm 5.0$ (SD) (HAMmton, 1960).

Twenty-seven control subjects, 9 females and 18 males were recruited through an advertisement in a local paper. Their mean ages were $29.6 \pm 8.4 \mathrm{yr}(\mathrm{SD})$ with an age range of 20-52 yr. Control subjects were also screened with a DIS and excluded if an axis I diagnosis or antisocial personality disorder was indicated. Mean Hamilton score was 1.6 \pm 0.96 (SD).

After informed consent was obtained, all subjects underwent a medical history, physical examination, endocrine history, complete blood count, serum electrolytes, blood chemistry screen, thyroid screen, and electrocardiogram. Subjects with evidence of significant medical illness, history of substance abuse, or current use of medications known to interfere with the HPA axis were excluded (CARROLL et al., 1983). We did not alter the medication regimen 
prescribed by ward physicians. Nineteen of the patients were on tricyclic antidepressants, 8 were on lithium, 1 was on monoamine oxidase inhibitor and 9 were on antipsychotic agents. Many of our subjects participated in a larger study which included multiple endocrine tests and therefore several received an ACTH stimulation test $24 \mathrm{~h}$ previous to the AVP challenge. As will be seen, there were no significant carry-over effects of the ACTH test.

\section{Arginine-vasopressin challenge}

All control subjects and depressed patients meeting the above criteria received 0.18 pressor-units $/ \mathrm{kg}$ body wt of AVP intramuscularly at 4.00 p.m. Blood was drawn immediately prior to injection and at $15,30,45,60$, and $90 \mathrm{~min}$ after injection. Samples were collected in an EDTA containing tube and centrifuged at $4^{\circ} \mathrm{C}$. Plasma was stored at $-70^{\circ} \mathrm{C}$ until assay. Side effect profiles were obtained at the time of each specimen retrieval.

\section{Dexamethasone suppression test (DST)}

The DST and AVP challenge test were separated by at least $48 \mathrm{~h}$. Dexamethasone (1 $\mathrm{mg}$ ) was given orally at $2300 \mathrm{~h}$. Blood was collected for cortisol determinations at 0800 and $1600 \mathrm{~h}$ the following day. DST nonsuppression was defined as any postdexamethasone cortisol $>5.0 \mu \mathrm{g} / \mathrm{dl}$.

Based on the results of dexamethasone suppression testing, patients with MDD were divided according to suppression status. Eight were non-suppressors (age 28.5 \pm 9.0 SD; 2 males, 6 females) and 19 were suppressors (age $32.1 \pm 10.5$ SD; 7 males, 11 females). The mean \pm SD Hamilton scores for NS were $18.3 \pm 4.6$ and for suppressors $19.2 \pm$ 5.3. One control subject was a non-suppressor.

\section{Biochemical assay procedure}

The University of Iowa Medical Research Facility Laboratory has developed and validated its own radioimmunoassay (RIA) for ACTH and cortisol. A specific description of these procedures can be found in PFOHL et al. (1985).

In this study ACTH was measured in two separate assays. The majority of the samples were assayed using the RIA described in PFOHL et al. (1985). The more recent samples were assayed by a new, more sensitive procedure in which the sensitivity for ACTH immunoreactivity in unextracted serum is $5 \mathrm{pg} / \mathrm{ml}$. Initial binding ranges from 30 to $40 \%$. The intraassay C.V.s are $7.1 \%, 5.5 \%$, and $4.8 \%$ for serum ACTH concentrations of 10 , 59 , and $408 \mathrm{pg} / \mathrm{ml}$, respectively. The corresponding interassay C.V.s are $6.2 \%, 12.4 \%$, and $11.5 \%$, respectively. All samples from the same subject are run in the same assay. In order to compare results from the two assays a regression line was drawn and the predicted comparable values were assigned to the original assay results.

The sensitivity of the RIA for cortisol in unextracted serums is $0.5 \mu \mathrm{g} / \mathrm{dl}$. The interassay C.V.s are $8.3 \%, 6.6 \%$, and $5.1 \%$ at serum cortisol concentrations of $2.7 \mu \mathrm{g} / \mathrm{dl}, 11.7 \mu \mathrm{g} / \mathrm{dl}$, and $23.6 \mu \mathrm{g} / \mathrm{dl}$, respectively. The interassay C.V.s are $14.6 \%, 13.4 \%$, and $16.7 \%$ at serum cortisol concentrations of $2.7,11.2$, and $23.6 \mu \mathrm{g} / \mathrm{dl}$, respectively. All samples from the same subject are run in the same assay. 


\section{Statistical analysis}

ACTH and cortisol response to AVP for patients with MDD (suppressors, S; nonsuppressors, NS) and controls (C) at basal, 15, 30, 60, and 90 min; peak; mean maximal increase ( $\Delta$ max); and integrated plasma levels (trapezoid rule) were compared using Student's $t$-tests or one-way ANOVAs. If the $F$-statistic was significant at the 0.05 level, the main effect means were compared with Tukey's studentized range test.

The effects of age and sex were controlled for by analysis of covariance. The effect of psychiatric medications were examined by grouping patients by psychiatric medications prescribed and comparing these groups to the remaining depressed patients using Student's $t$-test.

\section{RESULTS}

\section{$A C T H$ response to $A V P$ challenge}

There were no significant differences in ACTH among C, NS, and S for baseline, peak, $\Delta$ max levels, or integrated plasma levels. (Mean basal ACTH levels \pm SEM were 25.0 $\pm 4.5 \mathrm{pg} / \mathrm{ml}$ for $\mathrm{C}, 19.2 \pm 2.9 \mathrm{pg} / \mathrm{ml}$ for $\mathrm{S}$, and $15.5 \pm 3.6$ for NS. Mean $\Delta$ ACTH was $15.5 \pm 2.8 \mathrm{pg} / \mathrm{ml}$ for $\mathrm{C}, 12.0 \pm 2.0$ for $\mathrm{S}$, and $17.0 \pm 3.0$ for NS) (Fig. 1.)

As seen in Fig. 1 there is a trend for NS to have lower baseline ACTH values and lower subsequent levels at each time point. The $\Delta$ max values for NS and $C$, however, are quite similar. Nevertheless, with a $N$ of 8 for the NS patients, a type II error is possible.

\section{Vasopressin Stimulation Test: ACTH Mean Response}

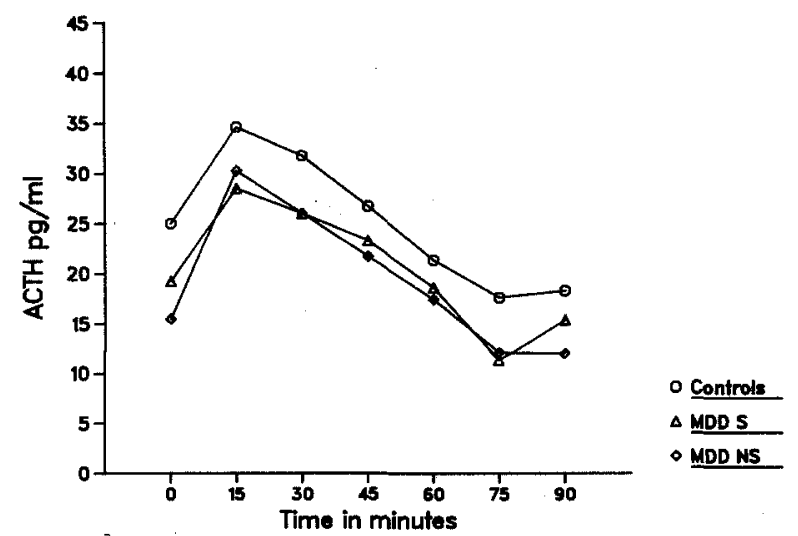

FIG. 1. ACTH response to 0.18 pressor units/ $\mathrm{kg}$ arginine vasopressin in controls $(\mathrm{O})$, in depressed dexamethasone non-suppressors $(\diamond)$ and suppressors $(\triangle)$.

\section{Cortisol response to $A V P$ challenge}

Mean ( \pm SEM) baseline plasma cortisol levels were similar between the MDD patients and control subjects $(\mathrm{MDD}=11.7 \pm 0.7 \mu \mathrm{g} / \mathrm{dl} ; \mathrm{C}=10.9 \pm 0.5 \mu \mathrm{g} / \mathrm{dl})$. The mean peak cortisol levels in the patients with $\mathrm{MDD}(20.8 \pm 1.1 \mu \mathrm{g} / \mathrm{dl})$ however was significantly greater than in the C group $(17.2 \pm 0.8 \mu \mathrm{g} / \mathrm{dl})(t=2.7, \mathrm{df}=48.5, P<0.01)$, and the mean $\Delta \max$ cortisol level was also significantly greater in patients with $\mathrm{MDD}(\mathrm{MDD}=9.2 \pm 0.95 \mu \mathrm{g} / \mathrm{dl}$; 
Vasopressin Stimulation Test: Cortisol Mean Response

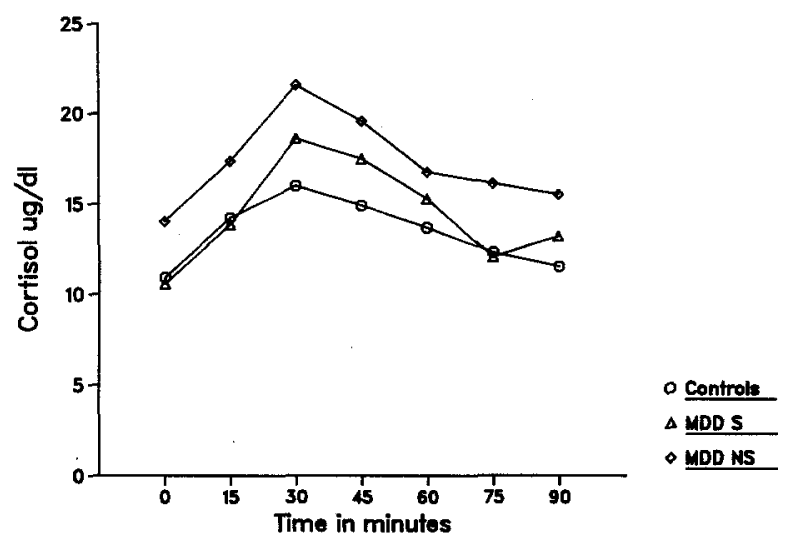

Fig. 2. Cortisol response to 0.18 pressor units/ $\mathrm{kg}$ or arginine vasopressin in controls $(O)$, in depressed dexamethasone non-suppressors $(\diamond)$ and suppressors $(\triangle)$.

$\mathrm{C}=6.3 \pm 0.6 \mu \mathrm{g} / \mathrm{dl}(t=-2.5, \mathrm{df}=45.7, P<0.02)$. The integrated plasma cortisol response curve was $1226 \mu \mathrm{g} \mathrm{min} / \mathrm{dl}$ in the MDD patients while it was $1057 \mu \mathrm{g} \mathrm{min} / \mathrm{dl}$ in the control subjects $(t=-2.2, \mathrm{df}=50.9, P<0.05)$.

When patients with MDD were divided into NS and S and three-group comparisons done, significant differences in mean baseline cortisol levels were found with NS (14.0 \pm 1.7 $\mu \mathrm{g} / \mathrm{dl})>\mathrm{S}(10.7 \pm 0.7)(F=3.6, \mathrm{df}=53, P<0.05$; Tukey, $P<0.05)$. The mean peak cortisol level in patients who were NS $(22.0 \pm 1.2 \mu \mathrm{g} / \mathrm{dl})$ and S $(20.4 \pm 1.4 \mu \mathrm{g} / \mathrm{dl})$ were nearly the same and probably represent maximal stimulation. (As mentioned above, mean peak cortisol values are significantly greater in patients than controls.) The $\Delta$ max cortisol levels of the patients who were $\mathrm{S}(9.7 \pm 1.2 \mu \mathrm{g} / \mathrm{dl})$ was significantly greater than control subjects $(F=3.6, \mathrm{df}=53, P<0.05$, Tukey $P<0.05)$. The $\Delta \max$ for NS patients was $7.9 \pm 1.5$ $\mu \mathrm{g} / \mathrm{dl})$.

When covariant analysis was used to evaluate the effects of age, gender, and age-gender interactions on cortisol response to AVP, no interactions were found at the $P<0.05$ level.

A comparison of ACTH and cortisol response to AVP in patients on and patients off tricyclic antidepressants, monomine oxidase inhibitors, lithium, and antipsychotics did not suggest any drug effect. AVP side effects were monitored throughout the challenge test on all subjects and none reported marked subjective distress. A number of subjects did report mild, transient GI sensations, or demonstrated facial pallor noticed only by an external observer. Although it was felt that such mild effects would not interfere with our findings, a systematic analysis of side effect profiles was done with control subjects and depressed patients compared using a standard chi square procedure. No differences in side effects profiles between patients and control subjects could be found.

As previously mentioned several of our subjects received an ACTH challenge test 24 $\mathrm{h}$ before the AVP was administered. In order to make certain there was no carry-over which might affect our results, mean $\Delta$ max cortisol and ACTH levels were compared in a control population, 6 of whom had received ACTH $24 \mathrm{~h}$ previously and 10 of whom had not. 
No significant differences were found and in fact cortisol mean $\Delta$ max was practically identical, 5.9 compared to 6.3. Mean $\Delta$ max ACTH tended to be smaller in subjects who had received ACTH, but this was not significant $(P=0.06)$.

\section{DISCUSSION}

One of the principal findings in our study is a similar ACTH response to AVP challenge in patients with MDD and control subjects. Although an inspection of Fig. 1 would suggest differences between NS and C, the standard errors of the mean ACTH values are quite high and statistical significance is not reached. This failure to attain significance may be in part due to the small $N(8)$ in the NS group. It should be noted that the largest differences are found in basal ACTH between $\mathrm{C}$ and NS. This might be explained by the marked hypercortisolemia in the NS, causing negative feedback to ACTH. After vasopressin stimulation, however, ACTH response was quite uniform between $\mathrm{C}$ and NS. Although type II error is possible, this finding is distinctly different from the findings reported when pituitary corticotrophs are stimulated by CRF (HolsBoER et al., 1984; Gold et al., 1984). A normal ACTH response to AVP supports our original hypothesis. Although ACTH secretion may be blunted in response to CRF receptor downregulation, AVP receptors are functioning normally as demonstrated by normal ACTH secretion. Furthermore, this data would suggest that elevated levels of circulating glucocorticoids do not interfere with ACTH response to AVP, even though unstimulated ACTH levels may be attenuated.

As might be expected from the recent reports of ACTH-cortisol dissociation (SHERMAN et al., 1984; PFOHL et al., 1985) results of cortisol response to AVP do not parallel those of ACTH. Depressed patients demonstrate a clear augmentation of cortisol secretion in response to AVP stimulation. Such a response is not explained by differences in age or sex. A possible factor which could influence our findings is the potential effect medication could have on cortisol. Retrospective analysis of this possibility, however, suggests that psychotropic medications do not play a role in our findings. This conclusion is further supported by WYSHAM (1986) who found no difference in ACTH or cortisol response to AVP in normal controls before and after a 2-week trial of imipramine $(150 \mathrm{mg} /$ day $)$.

As mentioned previously three prior investigators have measured cortisol response to vasopressin in patients with affective disorders. The first reports of a vasopressin challenge test came in 1969 by JAKOBSON et al. (1969). They report a "hyperactive response" in 3 of 16 patients. Control subjects were not employed and lysine vasopressin was used rather than arginine vasopressin. Further difficulties arise in interpreting these findings since they report than only 3 patients suffered from "endogenous" depression and 2 of their patients had their diagnosis changed to "schizophrenic psychosis with depressive features" during their hospitalization.

In 1972 CARROLL (1972) reported a small subgroup of depressed patients who failed to respond with a cortisol response to 5 units of intravenous lysine vasopressin. This data is difficult to interpret since again LVP was used rather than AVP. The stress of gastrointestinal discomfort, nausea, and vomiting with LVP may have overridden the vasopressin effect alone and again no control subjects were included.

The third study, KRAHN et al. (1985) found that 3 out of 7 depressed patients failed to respond to the intravenous administration of 3 pressor units of arginine vasopressin. This 
group was labeled "non-responders." We also found 5 subjects (both MDD and C) who did not have a meaningful cortisol response to our 0.18 pressor-unit $/ \mathrm{kg}$ body-wt intramuscular AVP challenge ( $\Delta \max <3 \mu \mathrm{g} / \mathrm{dl}$ ). It seems possible that each individual has a threshold plasma vasopressin level which must be reached in order to mount a cortisol response. Since KraHN et al. (1985) used a very small stimulus (3 pressor units AVP) regardless of weight or size, this non-response group may simply have not achieved the threshold level. It is also possible that depressed individuals have a threshold value which is greater than normals. Such an increased value could explain Krahn's "non-responders." If these "non-responders" are excluded from Krahn's data, the mean $\Delta$ max of the depressed group is actually greater than the controls as in our data.

A more recent investigation by vON BARDELEBEN et al. (1985) did not directly test depressed patients, but rather challenged normal control subjects who had been pretreated with dexamethasone to inhibit ACTH release. In this study neither vasopressin nor CRH alone were able to produce a marked elevation of ACTH in pretreated subjects. However, if both peptides were administered in combination, a marked release of ACTH and cortisol was demonstrated, suggesting abnormalities in the regulation of both peptides in depression. Although not directly comparable, these results contrast with our finding of normal AVP functioning. Future research with larger numbers of dexamethasone non-suppressors will probably be necessary to resolve these issues.

The fact that we find an increased cortisol response to AVP in depressed patients is consistent with other findings reported concerning HPA axis regulation in depression. AMSTERDAM et al. (1983) reported that depressed patients have an augmented cortisol response to exogenous ACTH when compared to controls. The augmented cortisol response found in our study similarly represents an example of increased cortisol secretion in response to ACTH stimulation; however, in this case the adrenal is responding to endogenous rather than exogenous ACTH. Since stimulated ACTH levels were the same in both MDD patients and control subjects, the adrenals of the MDD patients must have been hyperresponsive to ACTH. Such augmented cortisol response to ACTH in patients with depression is understandable in light of the fact that patients with hypercortisolemia secondary to primary endocrine disease such as Cushing's disease also have augmented cortisol response to ACTH stimulation (BESSER and EDWARDS, 1972).

In summary, our findings of normal ACTH response to AVP support the hypothesis that AVP receptors in pituitary corticotrophs are not downregulated as data suggest CRF receptors are. Our results also support the hypothesis that there is increased adrenal responsiveness to endogenous ACTH. Such a finding is consistent with those in other states of hypercortisolemia. These results are consistent with the theory that depression is related to chronic CRH hypersecretion and that stimulation with other ACTH secretagogues may shed further light on this possibility.

Acknowledgements-The authors wish to thank Jane Meller and Phillip Ecklund for assistance in collection and analysis of the data and Betty Stevens for help with manuscript preparation. This project was supported by Grant 1 RO1 MH 39259-01 from the National Institute of Mental Health and Grant RR59 of the Clinical Research Center's Grant Program. 


\section{REFERENCES}

American Psychiatric Association (1980) Diagnostic and Statistical Manual of Mental Disorder DSM-III, 3rd Edn. APA, Washington, DC.

Amsterdam, J. D., Winokur, A., Abelman, E., LuCKi, I. and Rickels, K. (1983) Cosyntropin (ACTH 124 ) stimulation test in depressed patients and healthy subjects. Am. J. Psychiat. 140, 907-909.

Besser, G. M. and Edwards, C. R. W. (1972) Cushing's syndrome. Clin. endocrin. Metab. 1, 451-490.

CARroul, B. J. (1972) The hypothalamic pituitary adrenal axis in depression. In Depressive Illness: Some Research Studies (Edited by Davies, B., Carroll, B. and Mowbray, R.), pp. 23-201. C. C. Thomas, Springfield, Ill.

Carroli, B. J., Feingerg, M., Greden, J. F., Tarika, J., Albala, A. A., Haskett, R. F., James, N. M., Kronfol, Z., Lohr, N., Steiner, M., De Vigne, J. P. and Young, E. (1981) A specific laboratory test for the diagnosis of melancholia. Archs gen. Psychiat. 38, 15-22.

CARRoul, B. J. (1983) Dexamethasone suppression test. In Handbook of Psychiatric Diagnostic Procedures (Edited by Hall, R. and Beresford, T.), pp. 1-28. Spectrum Publications, Philadelphia.

GIBBS, D. M. (1986) Vasopressin and oxytocin: hypothalamic modulators of the stress response: a review. Psychoneuroendocrinology 11, 131-140.

Gold, P. W., Chrousos, G., Kellner, C., Post, R., Roy, A., Augerinos, P., Schulte, H., Oldfield, E. and LORIAUX, L. (1984) Psychiatric implications of basic and clinical studies with corticotropin-releasing factor. Am. J. Psychiat. 141, 619-627.

GWINUP, G. (1965) Studies of the mechanism of vasopressin-induced steroid secretion in man. Metabolism 14, $1282-1286$.

GWinup, G., Sternberg, T., King, C. G. and Vernikos-Danellis, J. (1967) Vasopressin-induced ACTH secretion in man. J. clin. Endoc. 27, 927-930.

Hamiton, M. (1950) A rating scale for depression. J. Neurol. Neurosurg. Psychiat. 23, 56-62.

Holsboer, F., v Bardeleben, U., Gerken, A., Stulta, G. and Müller, O. (1984a) Blunted corticotropin and normal cortisol response to human corticotropin releasing factor in depression. New. Engl. J. Med. 311, 1127.

Holsboer, F., Müller, O. A., Doerr, H. G., Sippell, W. G., Stalla, G. K., Gerken, A., Steiger, A., Boll, E. and BENKERT, O. (1984b) ACTH and multisteroid response to corticotropin-releasing factor in depressive illness: relationship to multisteroid responses after ACTH stimulation and dexamethasone suppression. Psychoneuroendocrinology 9, 147-160.

Holsboer, F., Gerken, A., Stalla, G. K. and Müller, O. A. (1985) ACTH, cortisol and corticosterone output after ovine corticotropin releasing factor challenge during depression and after recovery. Biol. Psychiat. 20, 276-286.

Jakobson, T., Blomenthal, M., Hagman, H. and Heikkinen, E. (1969) The diurnal variation of urinary and plasma 17-hydroxy-corticosteroid (17-OHCS) levels and the plasma 17-OHCS response to lysine-8-vasopressin in depressive patients. J. Psychosom. Res. 13, 363-375.

Koch, B. and LUTZ-BUCHER, B. (1985) Specific receptors for vasopressin in the pituitary gland: evidence for down regulation and desensitization to adrenocorticotropin-releasing factors. Endocrinology 116, 671-676.

Krahn, D. D., Meller, W. H., Shafer, R. B. and Mordey, J. E. (1985) Cortisol response to vasopressin in depression. Biol. Psychial. 20, 918-921.

LANDON, J., JAMES, V. H. T. and STOKER, D. J. (1965) Plasma-cortisol response to lysine-vasopressin in comparison with other tests of human pituitary-adrenocortical function. Lancet ii, 1156-1159.

LOPEZ, J. F., KATHOL, R. G., JAECKLE, R. S. and MelleR, W. (1987) HPA axis response to insulin hypoglycemia in depression. Biol. Psychiat. 221, 153-166.

LUTZ-BUCHER, B. and KoCH, B. (1983) Characterization of specific receptors for vasopressin in the pituitary gland. Biochem. Biophys. Res. Comm. 115, 492-498.

MCCANN, S. M. and BroBEK, J. R. (1959) Evidence for a role of the supraopticohypophyseal system in regulation of adrenocorticotrophin secretion. Proc. Soc. exp. Biol. Med. 87, 318-324.

MCDonald, R. K. and Weise, V. K. (1956) Effect of pitressin on adrenocortical activity in man. Proc. Soc. exp. Biol. Med. 92, 107-109.

Nemeroff, C., Widerlov, E., Bissette, G., Walleus, H., Karlsson, I., Eklund, K., Kits, C. D., Loosen, P. T. and VALE, W. (1984) Elevated concentrations of CSF corticotropin releasing factor-like immunoreactivity in depressed patients. Science 226, 1342-1344.

Pfohl, B., Sherman, B., Schiechte, J. and Winokur, G. (1985) Differences in plasma ACTH and cortisol between depressed patients and normal controls. Biol. Psychiat. 20, 1055-1072.

RIVIER, C. and VALE, W. (1983) Influence of the frequency of ovine corticotrophin releasing factor adminstration on adrenocorticotropin and corticosterone secretion in the rat. Endocrinology, 113, 1422-1426.

RobtNs, L., Helzer, J., Croughn, J. and RATCLIFF, K. (1981) National institute of mental health diagnostic interview schedule: its history, characteristics and validity. Archs gen. Psychiat. 38, 381-389. 
Sachar, E. J., Hellman, L., Roffwarg, H. P., Halpern, F. S., Fukushima, D. K. and Gallagher, T. F. (1973) Disrupted 24-hour patterns of cortisol secretion in psychotic depression. Archs gen. Psychiat. 28, 19-24.

SaWChenkno, P. E., Swanson, L. W. and Vale, W. W. (1984) Corticotropin-releasing factor: co-expression within distinct subsets of oxytocin-, vasopressin-, and neurotensin-immunoreactive neurons in the hypothalamus of the male rat. $J$. Neurosci. 4, 1118-1129.

SChlessser, M. A., WinokUR, G. and Sherman, B. M. (1981) Hypothalamic-pituitary-adrenal axis activity in depressive illness. Archs gen. Psychiat. 37, 737-743.

Sherman, B. M., Schlechte, J. A. and Prohl, B. M. (1984) Dissociation of plasma cortisol and ACTH responses to dexamethasone in healthy subjects. Horm. Res. 20, 157-165.

SPINEDI, E. and NEGRO-VIIAR, A. (1983) Arginine vasopressin and adrenocorticotropin release: correlation between binding characteristics and biological activity in anterior pituitary dispersed cells. Endocrinology 114, 2247-2251.

TUCCI, J. R., ESPINER, E. A., JAGGER, P. I., LAULER, D. P. and THORN, G. W. (1968) Vasopressin in the evaluation of pituitary-adrenal function. Ann. int. Med. 69, 191-202.

Von Bardeleben, U., Holsboer, F., Stalla, G. K. and Müller, O. A. (1985) Combined administration of human corticotropin-releasing factor and lysine vasopressin induces escape from dexamethasone suppression in healthy subjects. Life Sci. 37, 1613-1618.

Wysham, C., ProH, B. and Kathol, R. G. (1986) Arginine vasopressin stimulation and imipramine. Biol. Psychiat. 21, 1353-1355. 